\title{
Pemetaan Kesesuaian Lahan Untuk Budidaya Rumput Laut Di Perairan Pulau Poteran, Kabupaten Sumenep, Jawa Timur
}

\author{
Hendra Irawan Ferdiansyah*, Ibnu Pratikto, Suryono \\ Departemen IImu Kelautan, Fakultas Perikanan dan IImu Kelautan, Universitas Diponegoro \\ Jl. Prof.H.Soedarto S.H, Tembalang,Semarang, Jawa Tengah 50275 Indonesia \\ ${ }^{\star}$ Corresponding author, e-mail : hendrairawanf@gmail.com
}

\begin{abstract}
ABSTRAK : Perairan Pulau Poteran merupakan salah satu wilayah yang berlokasi di Kabupaten Sumenep, Jawa Timur. Budidaya rumput laut di Pulau Poteran terdapat beberapa kendala dalam pengembangannya, yaitu dari sarana prasarana perikanan yang kurang memadai, keterbatasan pemahaman sumber daya manusia, modal, kelembagaan serta penentuan lokasi budidaya rumput laut. Penggunaan teknologi Sistem Informasi Geografis (SIG) di bidang kelautan dapat memberikan gagasan yang baru dalam kesesuaian lahan untuk budidaya rumput laut. Tujuan dilakukan penelitian ini adalah menganalisa lahan yang berpotensi untuk budidaya rumput laut di perairan Pulau Poteran dan mengetahui luas lahan yang efektif untuk pengembangan budidaya rumput laut di perairan Pulau Poteran. Metode penelitian yang digunakan adalah metode eksploratif dengan pendekatan analisa kuantitatif untuk mengetahui tingkatan dan luasan kesesuaian lahan budidaya rumput laut di perairan Pulau Poteran. Hasil penelitian menunjukkan bahwa luas untuk kategori sangat sesuai (S1) sebesar 7.335,59 ha, sedangkan untuk kategori sesuai (S2) memiliki luas sebesar 17.990,11 ha dan kategori tidak sesuai (S3) memiliki luas sebesar 24.665,28 ha. Luas lahan yang efektif untuk pengembangan budidaya rumput laut di perairan Pulau Poteran sebesar $4.401,35$ ha (60\% dari luas sangat sesuai) dengan jumlah rakit yang dioperasikan sebesar 785.955 unit dengan ukuran rakit $7 \times 8 \mathrm{~m}$.
\end{abstract}

Kata Kunci : Budidaya; Rumput Laut; Sistem Informasi Geografis; Pulau Poteran

\section{Mapping of Land Suitability for Seaweed Cultivation in Poteran Island Waters, Sumenep Regency, East Java}

\begin{abstract}
The territorial waters of Poteran Island are one of the areas located in Sumenep Regency, East Java. There are some problems in seaweed cultivation of Poteran Island, which are facilities, fishery infrastructure, limited human resources, financial, and institutional and the determination of the location of seaweed cultivation. The use of Geographic Information System (GIS) technology in the marine field can give new idea in land suitability for seaweed cultivation. The purpose of this research is to analyze the potential for seaweed cultivation in the waters of Poteran Island and know the effective land area for the development of seaweed cultivation in the waters of Poteran Island. The research method used is an exploratory method with a quantitative analysis approach to determine the level and extent of the suitability of seaweed cultivation in Poteran island waters. The results showed that the area for the very suitable category (S1) amounted to 7,335.59 hectare, while the corresponding category (S2) has an area of 17,990.11 hectare and the unsuitable category (S3) has an area of 24,665.28 hectare. Effective land area for the development of seaweed cultivation in the territorial waters of Poteran Island amounted to 4,401.35 hectare $(60 \%$ of the area is very suitable) with the number of rafts operated by 785,955 units with a raft size of $7 \times 8 \mathrm{~m}$.
\end{abstract}

Keywords: Seaweed Cultivation; Geographic Information Systems; Poteran Island

\section{PENDAHULUAN}

Budidaya rumput laut menjadi salah satu prospek di bidang kelautan yang cemerlang karena memiliki nilai jual yang tinggi. Secara ekonomi, rumput laut digunakan sebagai pangan, industri (bahan bangunan, kertas, dll); Farmasi sebagai obat, kosmetik, pertanian: pupuk, pakan 
ternak dan industri tekstil/batik menghasilkan warna alami sebagai bahan pewarna tekstil (Kustantiny, 2011). Menurut Salim dan Ernawati (2015), berdasarkan data yang ada baik produksi maupun ekspor rumput laut, Indonesia menempati urutan kedua setelah Filipina. Potensi pengembangan rumput laut di Indonesia mencapai 1,11 juta ha dengan produksi diperkirakan mencapai sebesar 167.937 ton per tahun.

Menurut Darmawati (2013), secara umum budidaya rumput laut di Indonesia masih dilakukan dengan cara tradisional, bersifat sederhana, dan belum banyak mendapat input teknologi dari luar. Faktor-faktor yang perlu diperhatikan dalam budidaya rumput laut, adalah: (1) pemilihan lokasi yang memenuhi persyaratan bagi jenis rumput laut yang akan dibudidayakan. Hal ini perlu karena ada perlakuan yang berbeda untuk tiap jenis rumput laut, (2) pemilihan atau seleksi bibit, penyediaan bibit, dan cara pembibitan yang tepat, (3) metode budidaya yang tepat, (4) pemeliharaan selama musim tanam, dan (5) metode panen dan perlakuan pasca panen yang benar.

Menurut Agus (2012), Sistem Informasi Geografis (SIG) merupakan sebuah sistem yang terdiri dari software dan hardware, data dan pengguna serta institusi untuk menyimpan data yang berhubungan dengan semua fenomena yang ada dimuka bumi. Teknologi SIG digunakan untuk mengatur dan memanfaatkan data geografis. Secara luas sistem ini dikenal sebagai satu teknik analisis spasial dalam berbagai bidang seperti pengelolaan kehutanan, perencanaan perkotaan, teknik sipil, pengelolaan permukiman, bisnis, dan studi lingkungan hidup (Budiyanto dan Muzayanah, 2018).

Pulau Poteran memiliki potensi ekonomi perikanan yang cukup tinggi, potensi tersebut merupakan hasil sumberdaya alam yang berada di wilayah Pulau Poteram. Potesi perikanan yang ada di Pulau Poteran berupa ikan teri, rajungan, ikan kerapu, lobster, kakap merah dan ekor kuning, budidaya rumput laut, mangrove maupun ikan laut hias. Budidaya rumput laut di Pulau Poteran termasuk sebagai komoditi terbesar dalam pengembangan di sektor perikanan Kabupaten Sumenep (Pamungkas et al., 2017). Untuk mendukung kegiatan tersebut perlu dilakukan analisis kesesuaian lahan dimana dalam menentukan lokasi budidaya rumput laut perlu diperhatikan beberapa persyaratan sebagai indikator yang mendukung kegiatan tersebut. Dalam penelitian ini dilakukan suatu kajian secara ekologis sebagai salah satu indikator untuk menentukan tingkat kesesuaian lahan untuk budidaya rumput laut di perairan Pulau Poteran dengan membuat peta kesesuaian lahan.

\section{MATERI DAN METODE}

Pada penelitian ini jenis data yang dipakai adalah data yang berkaitan dengan budidaya rumput laut seperti keterlindungan, substrat dasar, suhu, $\mathrm{pH}$, arus, kedalaman, MPT, DO, salinitas, fosfat dan nitrat. Berdasarkan data-data tersebut akan dibuat interpolasi yang bertujuan untuk memprediksi nilai grid yang tidak diwakili oleh titik sampel. Interpolasi yang digunakan yaitu Inverse Distance Weighting (IDW). Menurut Susetyo dan Agung (2016), metode ini membuat data dilakukan pembobotan selama interpolasi, sehingga pengaruh satu titik relatif terhadap titik lainnya dan semakin berkurang ketika jarak terhadap node grid semakin besar. Hasil dari poligon atau coverage (layer) ini yang digunakan untuk proses overlay.

\section{Pembobotan Kesesuaian Lahan Budidaya Rumput Laut}

Setiap parameter memiliki skor yang berbeda-beda sesuai dengan tingkat pengaruh dari masing-masing parameter terhadap hasil kesesuaian lahan rumput laut.

Menurut Jailani et al. (2015), setiap zona akan memiliki nilai kesesuaian dari setiap parameter yang dianggap paling penting dalam penentuan kesesuaian lahan. Berikut angka penilaian dan bobot berdasarkan parameter dan variable. Angka penilaian berdasarkan parameter diatas yaitu: 1 : Tidak Sesuai; 3 : Sesuai; 5 : Sangat Sesuai. Bobot berdasarkan pertimbangan variable dominan 1 : Tidak Penting; 2 : Penting; 3 : Sangat Penting. Untuk menentukan total bobot nilai dapat dilakukan dengan rumus sebagai berikut: $N=\sum(A x B)$. Keterangan : $N=$ Total bobot nilai; $A$ = Angka penilaian pada setiap kelas; $B=$ Bobot pada setiap kelas

Menurut Prahasta (2002), interval kelas kesesuaian lahan diperoleh berdasarkan metode Equal Interval. Setiap kelas diperoleh dari hasil jumlah skoring maksimum dikurangi dengan jumlah 
skoring minimum yang kemudian dibagi dengan jumlah kelas, kelas kesesuaian dibagi menjadi 3 yaitu : sangat sesuai, sesuai, dan tidak sesuai. Maka dapat dinyatakan dengan rumus : $\left(\Sigma(\mathrm{AxB}) \mathrm{Max}-\sum(\mathrm{AxB}) \mathrm{Min}\right) / 3$

Prahasta (2002) menjelaskan bahwa selang masing-masing kelas diteteapkan nilainya sebagai berikut : 30,7-68,4 Tidak Sesuai (S3); 68,5-106,2 Sesuai (S2); 106,3-145 Sangat Sesuai (S1). Kelas S1: sangat sesuai (highly suitable), yaitu lahan tidak mempunyai pembatas yang berat untuk suatu penggunaan tertentu secara lestari. Semua hambatan tidak mengurangi produktivitas atau keuntungan yang diperoleh dan tidak akan meningkatkan masukan yang diperlukan sehingga melampaui batas-batas yang masih dapat diterima. Kelas S2 : sesuai (suitable), yaitu lahan yang memiliki faktor pembatas sehingga dapat mengurangi tingkat produksi atau keuntungan yang diperoleh. Pembatas yang ada meningkatkan masukan atau biaya yang diperlukan. Serta meningkatkan masukan untuk mengusahakan lahan tersebut. Kelas S3 : tidak sesuai (not suitable), yaitu lahan yang mempunyai pembatas sangat berat/permanen, sehingga tidak mungkin dipergunakan untuk suatu penggunaan tertentu yang lestari. Lahan ini disarankan untuk dibiarkan tanpa dikelola atau dikelola secara alami, karena faktor pembatasnya bersifat permanen.

Tabel 1. Skor Kesesuaian Lahan Budidaya Rumput Laut

\begin{tabular}{|c|c|c|c|c|}
\hline Parameter & Kisaran & $\begin{array}{c}\text { Angka Penilaian } \\
\text { (A) }\end{array}$ & $\begin{array}{l}\text { Bobot } \\
\text { (B) }\end{array}$ & $\begin{array}{l}\text { Skor } \\
(\mathrm{AxB})\end{array}$ \\
\hline \multirow[t]{3}{*}{ Keterlindungan } & Terbuka & 1 & 3 & 3 \\
\hline & Terlindung & 3 & & 9 \\
\hline & Sangat Terlindung & 5 & & 15 \\
\hline \multirow[t]{3}{*}{ Arus $(\mathrm{cm} / \mathrm{dt})$} & $<10 \&>40$ & 1 & 3 & 3 \\
\hline & $>10-<25 \&>40-60$ & 3 & & 9 \\
\hline & $25-40$ & 5 & & 15 \\
\hline \multirow[t]{3}{*}{ Kedalaman $(\mathrm{m})$} & $<2 \&>10$ & 1 & 3 & 3 \\
\hline & $2-<3$ atau $>5-<10$ & 3 & & 9 \\
\hline & $3-5$ & 5 & & 15 \\
\hline \multirow{4}{*}{$\begin{array}{l}\text { Dasar perairan } \\
\text { (Substrat) }\end{array}$} & Lumpur \& Karang & 1 & 3 & 3 \\
\hline & Pasir Berlumpur Sedang & 3 & & 9 \\
\hline & Pasir Halus, Pecahan karang \& & 5 & & \\
\hline & Makro Alga & & & 15 \\
\hline \multirow{3}{*}{ Salinitas (ppt) } & $<25 \&>37$ & 1 & 3 & 3 \\
\hline & $>25-<28$ atau $>34-<37$ & 3 & & 9 \\
\hline & $28-34$ & 5 & & 15 \\
\hline \multirow[t]{3}{*}{ Suhu $\left({ }^{\circ} \mathrm{C}\right)$} & $<20 \&>30$ & 1 & 3 & 3 \\
\hline & $20-24$ & 3 & & 9 \\
\hline & $24-30$ & 5 & & 15 \\
\hline \multirow[t]{3}{*}{ MPT (mg/l) } & $>80$ & 1 & 2 & 2 \\
\hline & $>25->80$ & 3 & & 6 \\
\hline & $<25$ & 5 & & 10 \\
\hline \multirow[t]{3}{*}{$\mathrm{pH}$} & $<4$ atau $>9,5$ & 1 & 2 & 2 \\
\hline & $4-6,4$ atau $8,5-9$ & 3 & & $\overline{6}$ \\
\hline & $6,5-8,5$ & 5 & & 10 \\
\hline \multirow{3}{*}{$\mathrm{DO}(\mathrm{mg} / \mathrm{l})$} & $<3$ & 1 & 3 & 3 \\
\hline & $3-7$ & 3 & & 9 \\
\hline & $>7$ & 5 & & 15 \\
\hline \multirow[t]{3}{*}{ Nitrat (mg/l) } & $<0,01$ atau $>0,5$ & 1 & 2 & 2 \\
\hline & $>0,01-<0,04$ atau $>0,1-<0,5$ & 3 & & 6 \\
\hline & $0,04-0,1$ & 5 & & 10 \\
\hline \multirow{3}{*}{ Fosfat (mg/l) } & $<0,01$ atau $>1$ & 1 & 2 & 2 \\
\hline & $>0,01-<0,1$ atau $>0,2-<1$ & 3 & & 6 \\
\hline & $0,1-0,2$ & 5 & & 10 \\
\hline
\end{tabular}




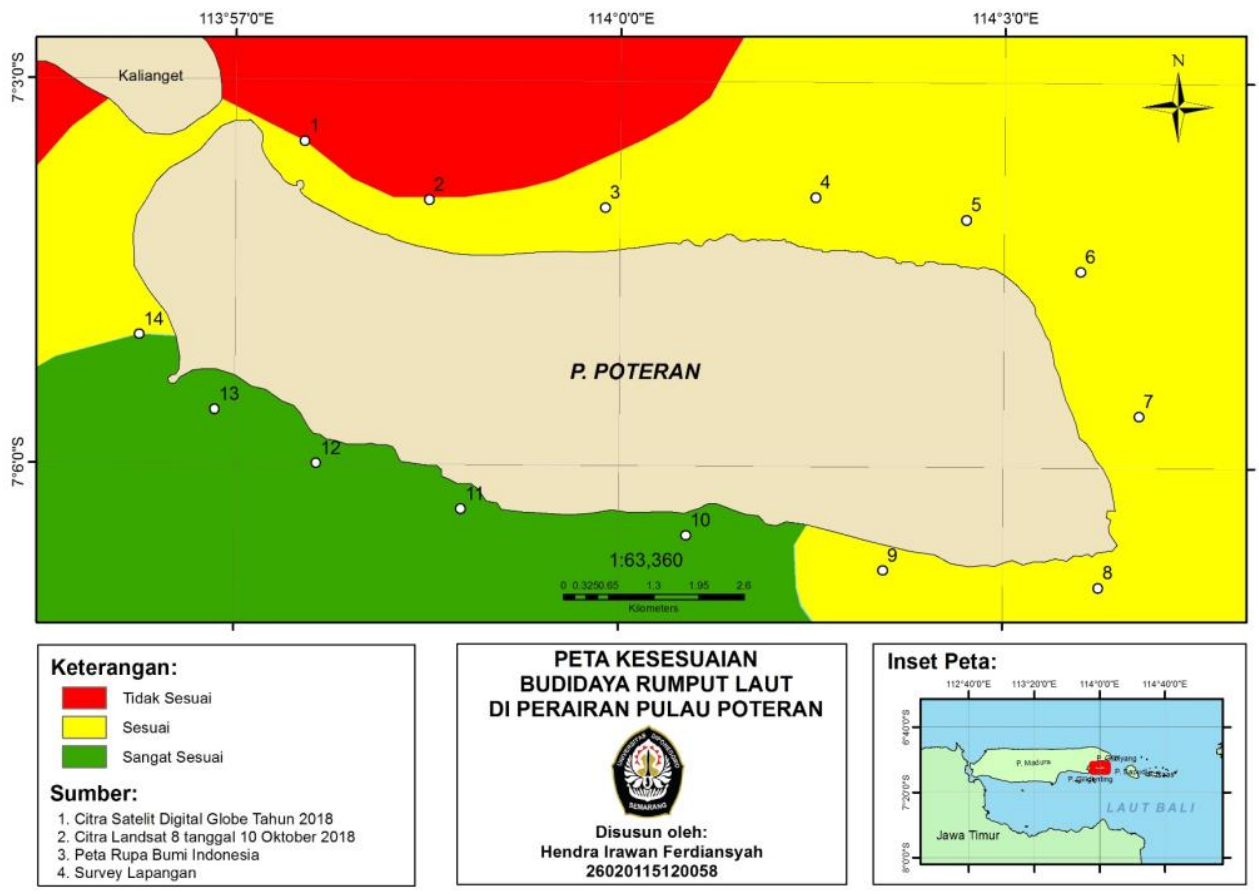

Gambar 1. Peta Kesesuaian Lahan Budidaya Rumput Laut Perairan pulau Poteran

\section{HASIL DAN PEMBAHASAN}

Penentuan lokasi budidaya rumput laut dilakukan dengan cara overlay tiap-tiap variabel yang telah diperoleh. Peta kesesuaian lahan disajikan pada Gambar 1. Peta tersebut selanjutnya dilakukan analisis luasan pada tiap kesesuaian dengan menggunakan Sistem Informasi Geografis yang disajikan pada Tabel 3.

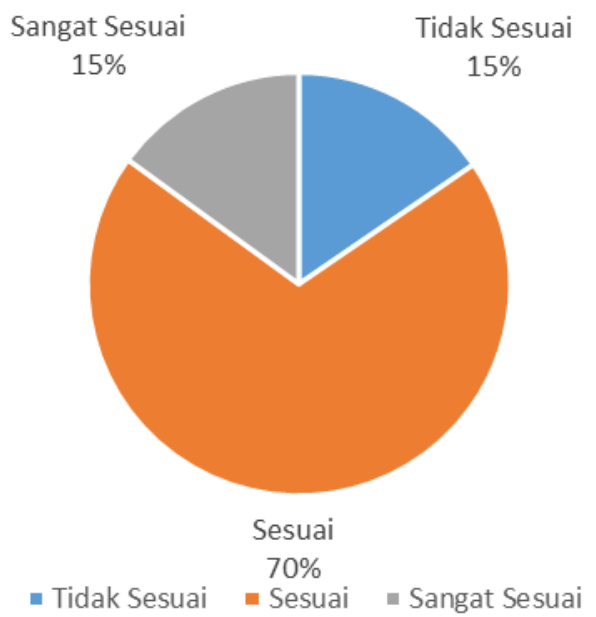

Gambar 2. Peta Kesesuaian Lahan Budidaya Rumput Laut Perairan Pulau Poteran

Tabel 3. Luas Kesesuaian Lahan di Perairan Pulau Poteran

\begin{tabular}{cc}
\hline Kategori & Luas (ha) \\
\hline Sangat Sesuai (S1) & $7.335,59$ \\
Sesuai (S2) & $17.990,11$ \\
Tidak Sesuai (S3) & $24.665,28$ \\
\hline
\end{tabular}


Presentase kesesuaian budidaya rumput laut di perairan Pulau Poteran memiliki 3 kategori. Kategori tidak sesuai (S3) memiliki presentase sebesar 49\%, kategori sesuai (S2) memiliki presentase sebesar $36 \%$ dan untuk kategori sangat sesuai (S1) yaitu zona yang sangat direkomendasikan untuk dilakukannya budidaya rumput laut memiliki presentase sebesar $15 \%$.

\section{KESIMPULAN}

Hasil analisis kesesuaian lahan untuk pengembangan budidaya rumput laut di lokasi penelitian yang sangat sesuai (S1) sebesar 2.976,15 ha. Luas lahan yang efektif untuk pengembangan budidaya rumput laut sebesar 1785,69 ha (60\% dari luas sangat sesuai) dengan jumlah rakit yang dioperasikan sebesar 785.955 unit dengan ukuran rakit 7 × $8 \mathrm{~m}\left(56 \mathrm{~m}^{2}\right)$.

\section{DAFTAR PUSTAKA}

Agus, F. 2012. Kajian Tentang Integrasi 'GIS Participatory-Decision Support' dalam Manajemen Tata Ruang Suatu Wilayah. Informatika Mulawarman: Jurnal IImiah IImu Komputer, 7(1):1-7

Agustina, N.A., Nirmala. I.W. \& Vivi, D.P. 2017. Kriteria Lahan untuk Budidaya Rumput Laut (Eucheuma cottonii) di Pulau Gili Genting, Madura. Seminar Nasional Kelautan XII. Universitas Hang Tuah. Surabaya.

Budiyanto, E. \& Muzayanah. 2018. Pendalaman Materi Geografi : Sistem Informasi Geografis. Kementerian Riset, Teknologi, dan Pendidikan Tinggi.

Darmawati. 2013. Analisis Laju Pertumbuhan Rumput Laut Kappaphycus alvarezii yang Ditanam pada Berbagai Kedalaman. Octopus: Jurnal IImu Perikanan, 2(2):184-191

Gazali. I., Bambang. R.W. \& Ruslan, W. 2013. Evaluasi Dampak Pembuangan Limbah Cair Pabrik Kertas Terhadap Kualitas Air Sungai Klinter Kabupaten Nganjuk. Jurnal Keteknikan Pertanian Tropis dan Biosistem. 1(2):1-8.

Jailani, A.Q., Endang, Y.H. \& Bambang, S. 2015. Studi Kelayakan Lahan Budidaya Rumput Laut Eucheuma cottonii di Kecamatan Bluto Sumenep Madura Jawa Timur. Jurnal Manusia dan Lingkungan, 22(2):211-216.

Kustantiny, A. 2011. Prospek Rumput Laut sebagai Bahan Baku Industri Kertas yang Ramah Lingkungan. Jurnal Rumput Laut 7(3):275-285.

Nirmala, K., Ratnasari, A. \& Budiman, S. 2014. Penentuan Kesesuaian Lokasi Budidaya Rumput Laut di Perairan Teluk Gerupuk - Nusa Tenggara Barat Menggunakan Penginderaan Jauh dan SIG. Jurnal Akuakultur Indonesia, 13(1):73-82

Pamungkas, A., Aunurohim, Taslim, E., Tatas, Aries, S. \& Jaelani, L.M. 2017. Pulau Poteran Menuju Pulau Kecil Mandiri. Media Bersaudara. Surabaya. 150 hal

Prahasta, E. 2002. Konsep-konsep Dasar Sistem Informasi Geografi. Informatika Bandung. Bandung.

Salim, Z. \& Ernawati. 2015. Info Komoditi Rumput Laut. Badan Pengkajian dan Pengembangan Kebijakan Perdagangan 118 pp. Jakarta.

Susetyo, D.B. \& Agung, S. 2016. Perbandingan Metode Interpolasi Terhadap Hasil Pembentukan Digital Terrain Model (DTM). Badan Informasi Geospasial. Bogor. 